Renewable energy supply and storage

Guide for planners \& developers in sparsely populated areas

(10) Nordic Council of Ministers 



\section{Renewable energy supply and storage}

Guide for planners \& developers in sparsely populated areas

Peter Bode Nielsen, Morten Hørmann, Jakob Nymann Rud and Frederik Møller Laugesen

TemaNord 2016:563 


\section{Renewable energy supply and storage}

Guide for planners \& developers in sparsely populated areas

Peter Bode Nielsen, Morten Hørmann, Jakob Nymann Rud and Frederik Møller Laugesen

ISBN 978-92-893-4805-8 (PRINT)

ISBN 978-92-893-4806-5 (PDF)

ISBN 978-92-893-4807-2 (EPUB)

http://dx.doi.org/10.6027/TN2016-563

TemaNord 2016:563

ISSN $0908-6692$

Standard: PDF/UA-1

ISO 14289-1

(c) Nordic Council of Ministers 2016

Layout: Hanne Lebech

Cover photo: COWI A/S

Other photos: Torill Meistad, NER

Print: Rosendahls-Schultz Grafisk

Printed in Denmark

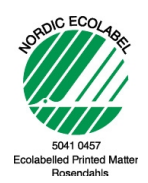

Although the Nordic Council of Ministers funded this publication, the contents do not necessarily reflect its views, policies or recommendations.

\section{Nordic co-operation}

Nordic co-operation is one of the world's most extensive forms of regional collaboration, involving Denmark, Finland, Iceland, Norway, Sweden, the Faroe Islands, Greenland, and Åland.

Nordic co-operation has firm traditions in politics, the economy, and culture. It plays an important role in European and international collaboration, and aims at creating a strong Nordic community in a strong Europe.

Nordic co-operation seeks to safeguard Nordic and regional interests and principles in the global community. Shared Nordic values help the region solidify its position as one of the world's most innovative and competitive. 


\section{Contents}

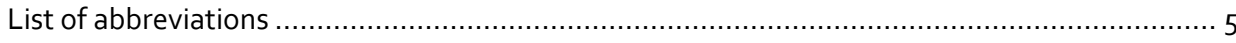

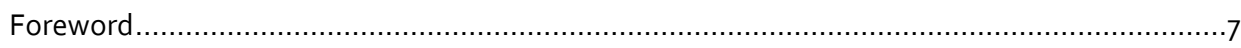

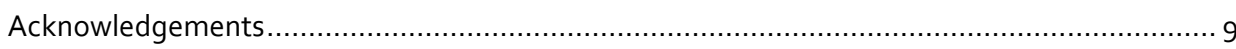

1. Introduction to a renewable energy system in sparsely populated areas ........................11

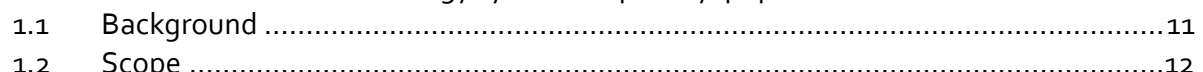

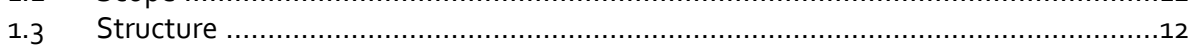

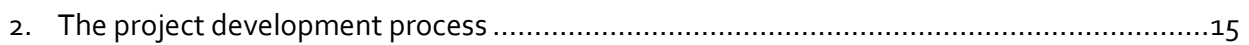

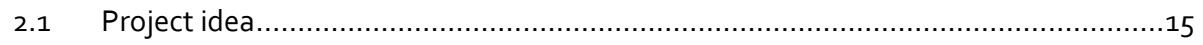

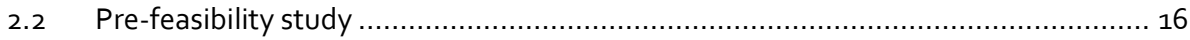

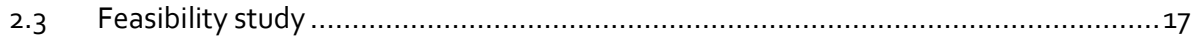

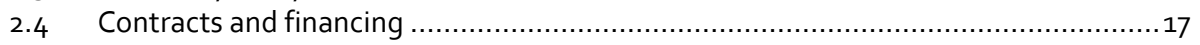

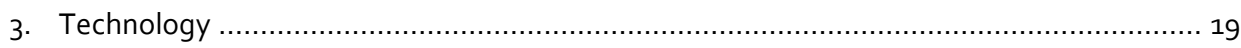

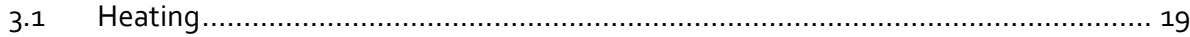

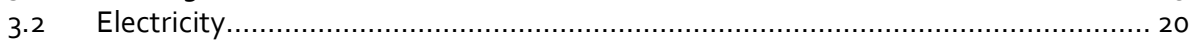

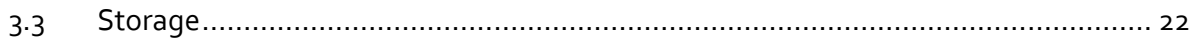

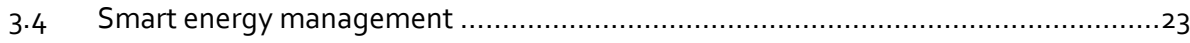

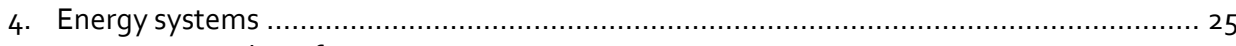

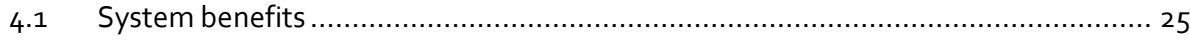

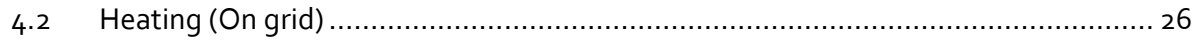

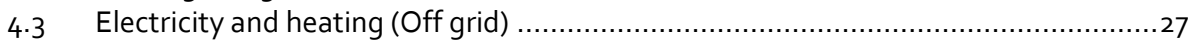

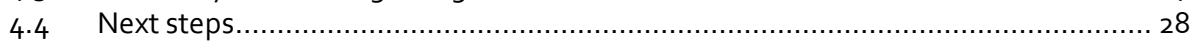

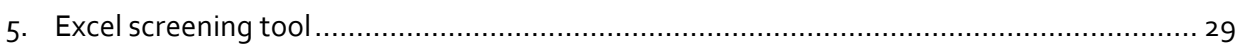

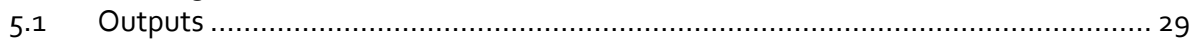

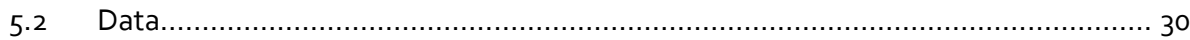

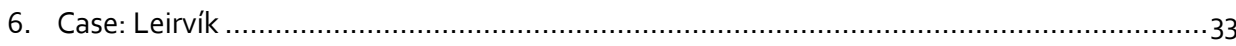

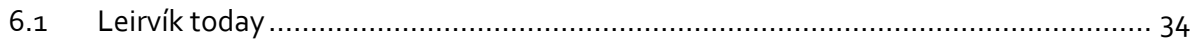

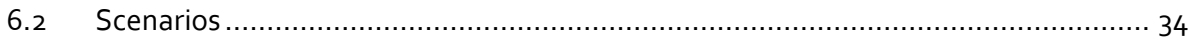

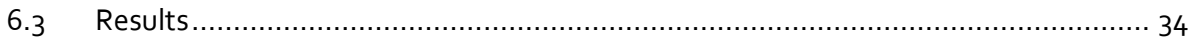

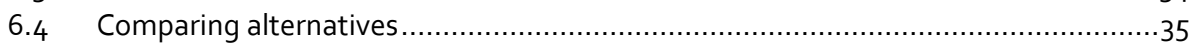

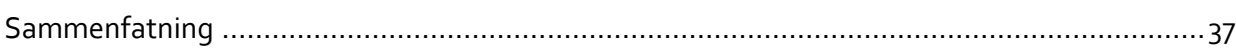

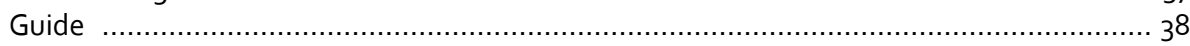

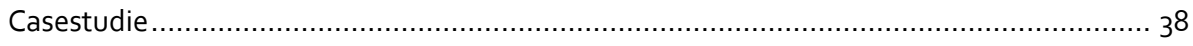




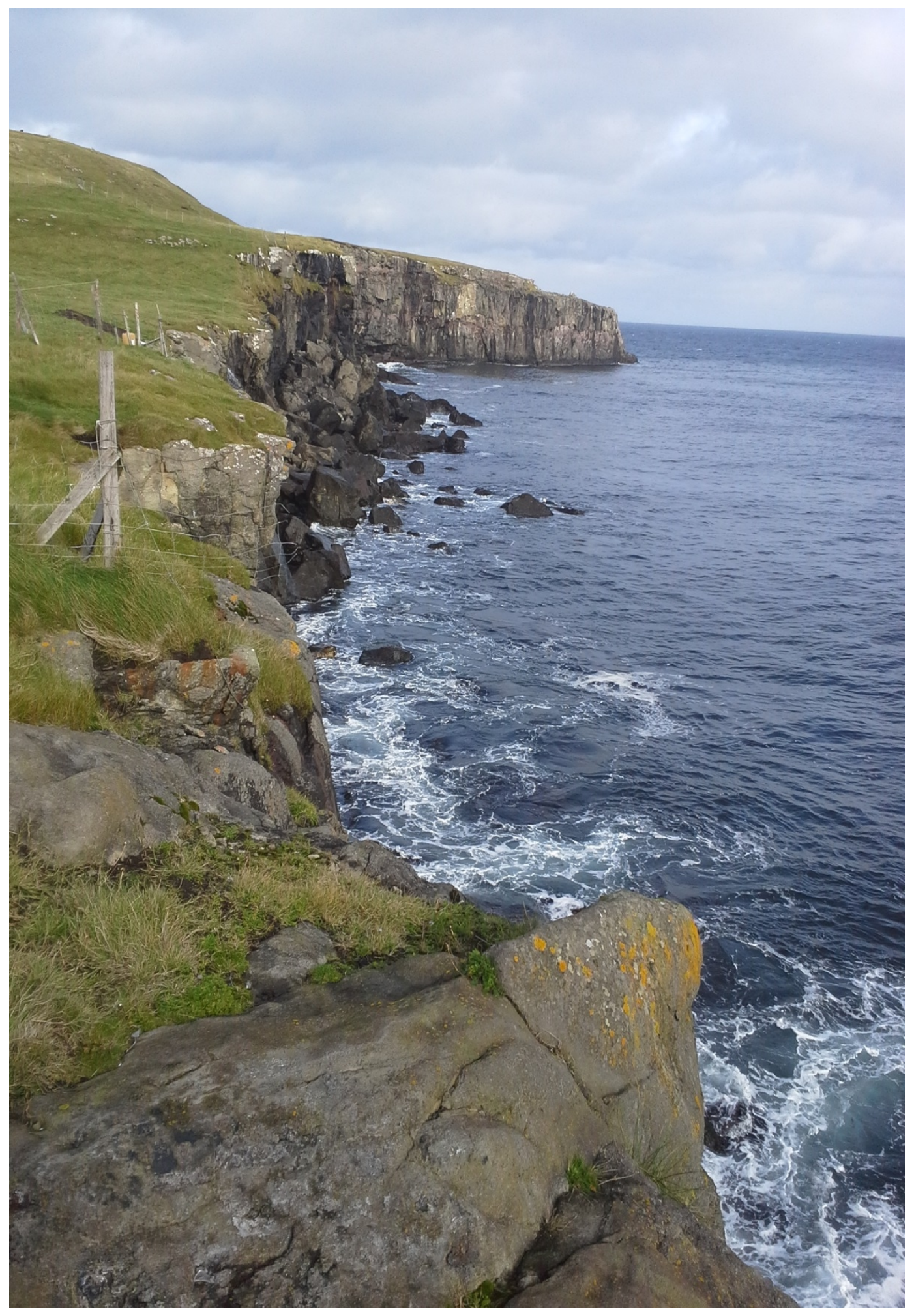




\section{List of abbreviations}

- COP: Coefficient Of Performance. The rate of conversion of energy into heat most notably used in relation to heat pumps.

- CAPEX: CAPital Expenditure.

- EIA: Environmental Impact Assessment.

- EPC: Engineering, Procurement and Contracting.

- FID: Final Investment Decision.

- FS: Feasibility Study.

- O\&M: Operations and maintenance.

- OPEX: Operational EXpenditur.

- PFS: Pre-Feasibility Study.

- RE: Renewable Energy.

- RES: Renewable Energy Source.

- RES share: Renewable Energy Source share. The share of renewable energy used out of the total energy used.

- SIA: Social Impact Assessment. 


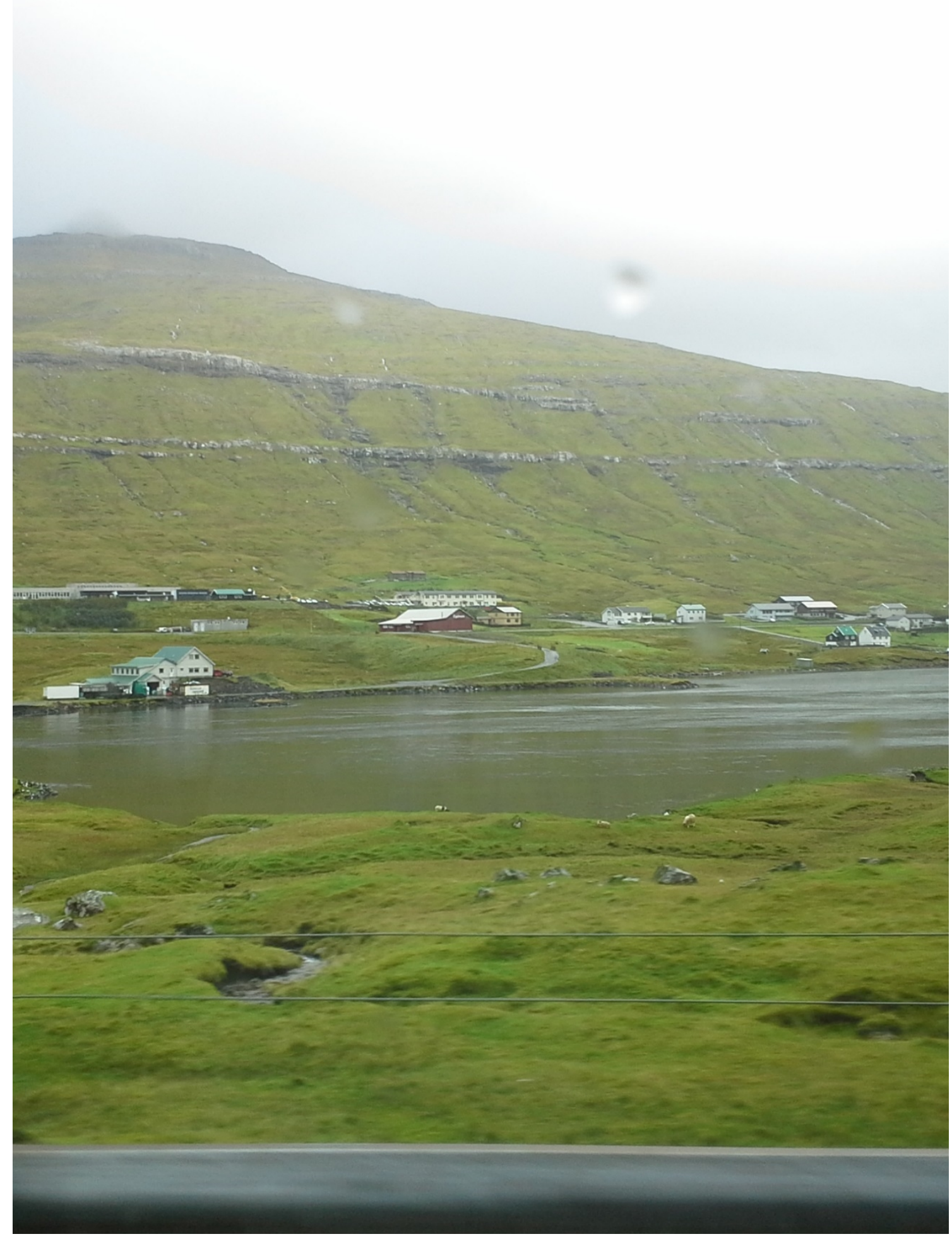




\section{Foreword}

There is a strong and growing focus on the implementation of renewable energy, smart grid and energy storage technologies, not least in the Nordic countries. The Nordic countries furthermore have a strong position in renewable energy solutions such as wind, water and biogas due to a well-functioning energy market and intergovernmental cooperation.

Nordic Energy Research presents this guide as a practical tool for energy planners and project developers with the aim of providing sustainable energy and storage capacity to sparsely populated areas. The target audience is initiative takers in villages and sparsely populated communities with the aim of implementing $100 \%$ renewable energy solutions or reducing their dependence on fossil fuels. An example study from the Faroe Islands is included in this guide. However, the planning tool can also be utilised in energy islands in other parts of the North West Atlantic and the rest of the world.

The focus of this guide is on proven technologies that are essentially off-theshelf products. Because small communities in sparsely populated areas are very selfreliant it is important that the energy solutions have proven to be reliable. This approach is also a testament to the fact that today's off-the-shelf products are sufficient to design affordable systems, which rely entirely on renewable energy sources.

This guide can be seen as a practical supplement to Nordic Energy Research's publication Nordic Energy Technology Perspectives 2016, which is a full-fledged analysis on how the Nordic Countries (Denmark, Iceland, Finland, Norway and Sweden) can achieve their ambitious climate energy targets for 2030 and 2050 in the most cost effective way. The North Western part of the Atlantic sea will be the subject of a new comprehensive study conducted by Nordic Energy Research, and the report Energy in West Nordic areas and the Arctic (EWA) will be presented in early 2018. 
While NETP 2016 and EWA present energy technology scenarios in a Nordic and Arctic perspective, this guide provides a tool for practical implementing of energy systems for the future at a local level.

We hope that you find this guide useful!

Hans Jørgen Koch

CEO

Nordic Energy Research 


\section{Acknowledgements}

This publication was prepared by COWI A/S on behalf of the Nordic Energy Research (NER). The work has been financed by the Nordic Council of Ministers, Nordic Committee of Senior Officials for Energy Policy (EK-E)

The guide's development was managed by Peter Bode Nielsen, and the guide was developed by Morten Hørmann, Jakob Nymann Rud and Frederik Møller Laugesen at COWI A/S.

The work was guided by senior adviser Torill Meistad (NER) who together with Kári Mannbjørn Mortensen and Bjarti Thomsen, Umhvørvisstovan (The Environment Agency of the Faroe Islands) and Ragnar Ásmundsson (member of reference group) provided important review and comments that helped to improve the document.

Thanks for the contributions from all members of the reference group:

- Ragnar Ásmundsson, Varmalausnir, Iceland

- Ole Ziemer, Nukissiorfiit, Greenland

- Johan Wasberg, Merinova, Finland

- Robert Mansen, Åland teknologi och Energicentrum, Åland

- Göran Hamlund, Elinorr, Sweden

- Ivar Blikø, Smart Grid Services cluster, Norway 


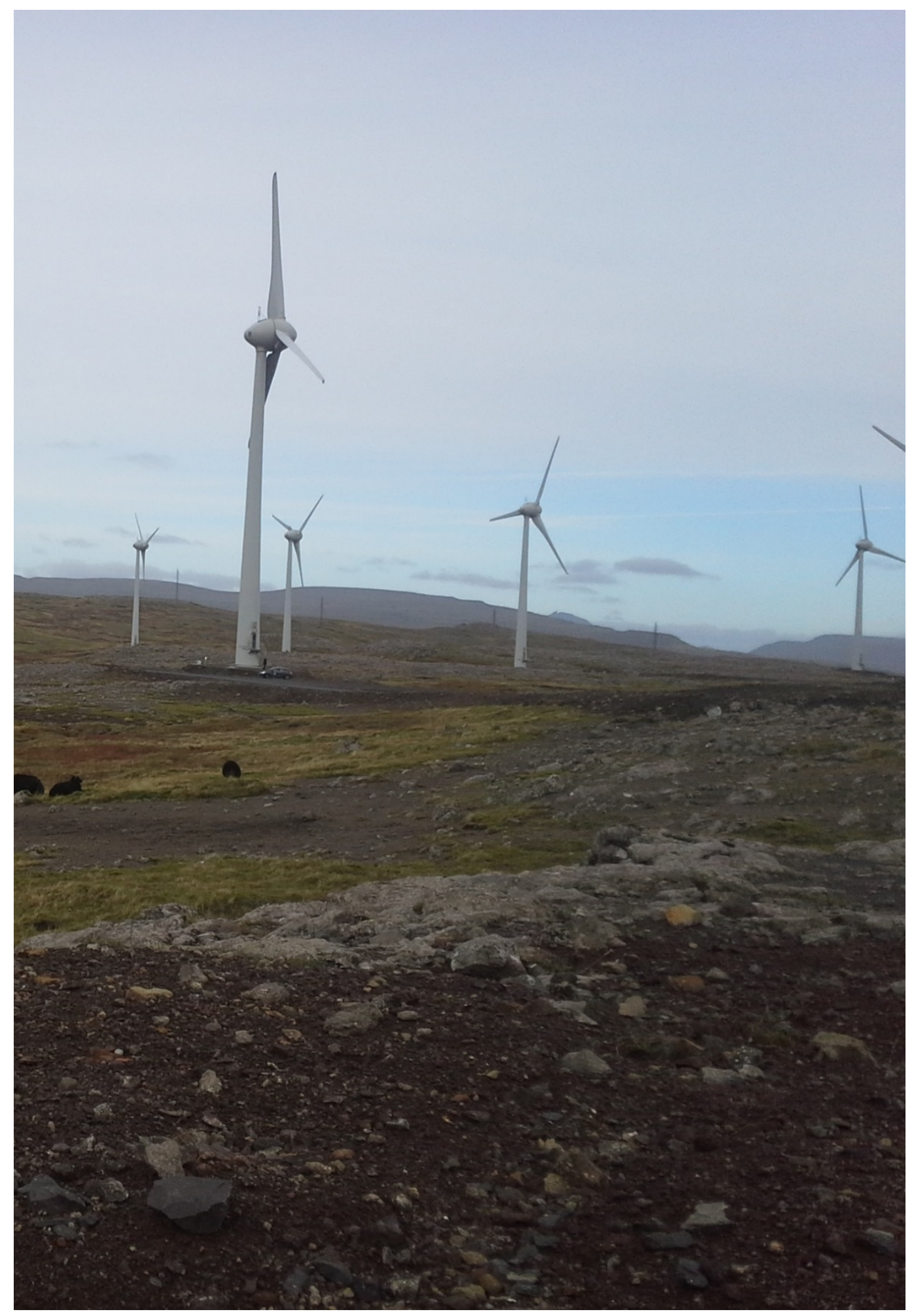




\section{Introduction to a renewable energy system in sparsely populated areas}

There is a strong and growing focus on the implementation of renewable energy and energy storage technologies. The Nordic countries have a strong position in Renewable Energy (RE) solutions such as wind, water and bioenergy/fuel due to a wellfunctioning energy market and inter-governmental cooperation.

\subsection{Background}

The Nordic countries have set ambitious climate and energy supply goals. The Nordic action plan programme on energy cooperation, 2014-2017, reflects these ambitions. Focus is on the implementation of the available renewable energy sources and energy storage technologies, which plays a key role in the further development of a fossil free energy system in the Nordic region.

In small communities and sparsely populated areas the challenge of integrating renewable energy is different than in bigger systems which have the opportunity to rely on multiple energy technologies. The lack of economies of scale in smaller systems and the inflexible nature of many renewable energy production technologies can lead to expensive solutions. This can be a barrier for the transition from traditional fossil energy supply to renewable energy supply, for meeting policy objectives and for becoming independent of imported fuels. On the other hand, the small scale nature of the small communities and sparsely populated areas provide an opportunity for a faster transition to an energy system based on 100\% renewable energy.

This guide provides guidelines to develop affordable - and reliable - renewable energy projects by using off-the-shelf technology. The focus on known and proven off-the-shelf products addresses two major concerns in energy supply in sparsely populated areas: affordability and security of supply. This guide is not an exploration of innovative and state of the art technological solutions - it is rather a road map to large scale implementation of renewable energy in the sparsely populated areas of The Nordic Region. 


\subsection{Scope}

The Nordic countries all have ambitious goals regarding the transition to a fossil free society. It is broadly accepted in the Nordic countries that one key to a $100 \%$ fossil free society is electrification. Electrification has the potential to increase the share of intermittent electricity production (e.g. wind and solar power) by increasing demand flexibility and encouraging a symbiotic relationship between energy production and energy use. In short, we try to address what we see as the main challenge in renewable energy production - balancing intermittent electricity production.

This guide will primarily focus on the electrification of heat generation, and the production, storage and management of renewable electricity

Another aspect of this guide is the distinction between on-grid communities and off-grid communities and how they differ when looking at solutions for becoming independent of fossil fuels.

An on-grid village is subject to the national goals for the RE share in the grid, thus local RE production has very little overall effect, and will most likely come at a higher cost.

An off-grid village cannot rely on the national targets on RE in the grid, to provide them with investment-free RE. Thus, they need both production, storage and management of their electricity.

This guide will provide project development support for both the on-grid and offgrid scenario, which are the following:

- On-grid: Projects increasing local electrification of heating.

- Off-grid: Projects increasing local electrification and generating renewable electricity.

The development of a renewable energy project requires careful preparation and it is hoped that this guide will facilitate project developers and energy planners in their preparation of successful projects.

\subsection{Structure}

This document is an executive summary of and introduction to a larger collection of documents which together constitute "The Guide". The complete guide consists of this overview Guide, four Guide Reports and an Excel based screening tool for renewable energy projects.

The remainder of this executive summary is structured as follows: 
- Chapter 2: The project development process. In which we briefly describe the major milestones in the project development process.

- Chapter 3: Technologies. In which we briefly describe the main technologies for electrification of heating, production of electricity from renewable energy sources and storage of heat and electricity.

- Chapter 4: Energy systems. In which we briefly describe a selection of possible system designs for delivering heating and electricity based on $100 \%$ renewable energy. This includes a description of how the system employ smart grid technology to reap system benefits.

- Chapter 5: Excel screening tool. In which we describe the Excel tool we have developed to help local planners and decision makers perform an initial economic screening of up to three alternative energy systems for supplying heating and electricity based on $100 \%$ renewable energy.

- Chapter 6: Leirvík case. In which we describe the case study of Leirvík in the Faroe Islands, where we investigated the feasibility of three alternative heating solutions based on renewable energy to replace the existing oil based heating systems.

The following appendices and reports are available for further information:

- Guide Report no. 1: Case report from Leirvík in the Faeroe Islands including technical appendices to document the design of three case scenarios.

- Guide Report no. 2: Catalogue of technologies and systems which presents hard facts about each technology and how the technologies fit together.

- Guide Report no. 3: Appendix on financial and cost benefit analysis.

- Guide Report no. 4: Appendix on organisational, social and regulatory considerations.

- Excel screening tool for evaluating the economic feasibility of 3 alternative user defined scenarios. 


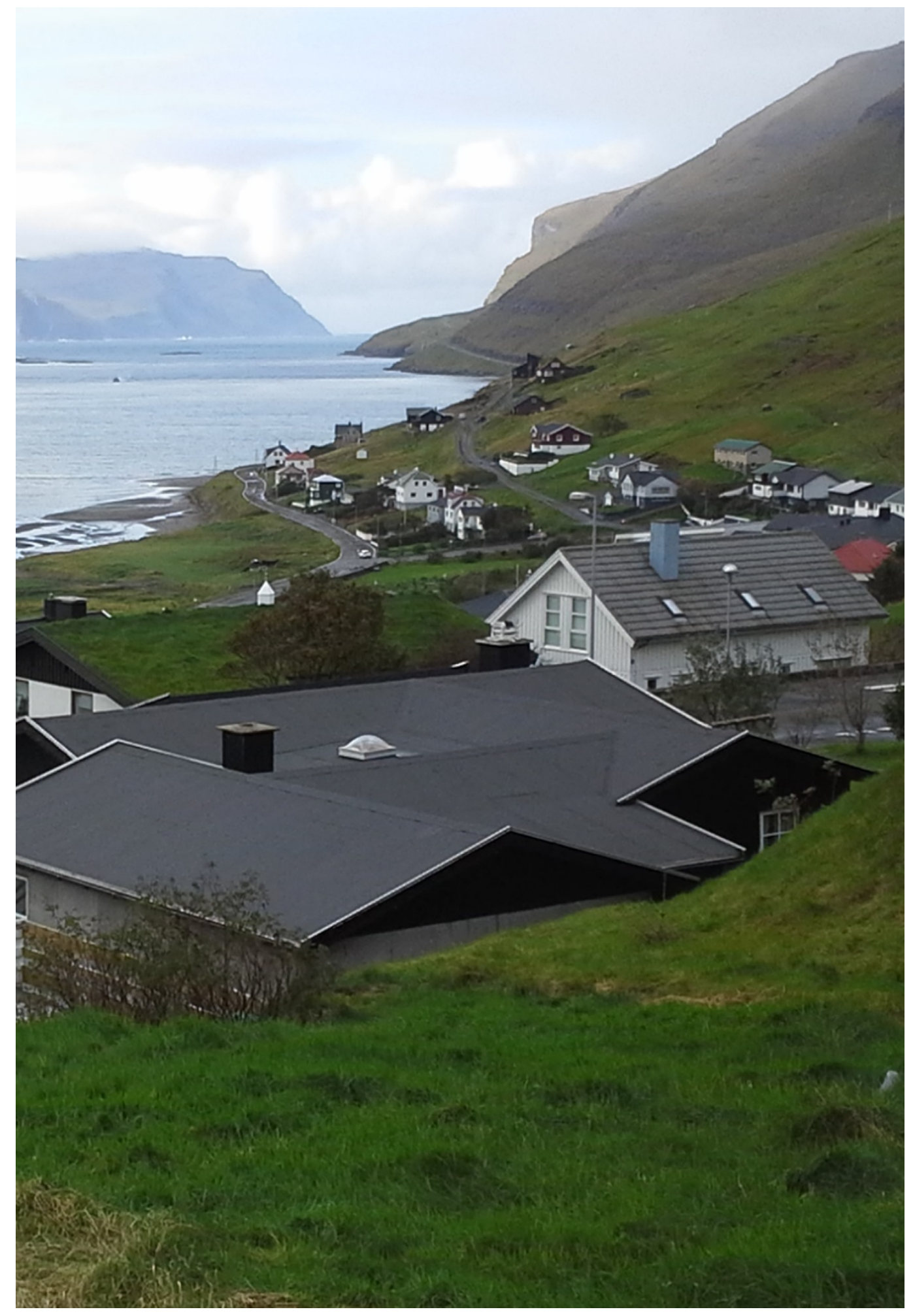




\section{The project development process}

In this section we briefly describe the process of developing a renewable energy project and how you can use this guide for support in that process. Developing a renewable energy project is no different from the process of developing other construction projects. In most construction projects the main project stages are:

- Project development:

- Project idea.

- Pre-feasibility study.

- Feasibility study.

- Contracts and financing.

- Project implementation:

- Design.

- Construction.

- Commissioning.

This guide goes in-depth with the project development stages.

In Guide Report no. 4 we go into detail with the project development process including stakeholder consultations and preparation of pre-feasibility and feasibility studies. The report is structured as a check list for project developers to keep the project development process on track. Below you will find a brief description of each of the project development stages.

\subsection{Project idea}

The idea for a renewable energy project may have its origins in many different sources - e.g. the owner of an industrial enterprise, a local enthusiast or a professional project developer. The best ideas are the ones founded on knowledge of existing technologies and the needs and expectations of the local community. In chapters 3 and 4 we describe a range of technologies, their benefits and shortcomings as well as how these 
technologies can be combined to achieve synergies. We hope this will inspire you to develop renewable energy projects in your local community.

A renewable energy project can provide many advantages such as:

- Cheaper energy supply.

- Environmentally friendly solutions.

- Reduction in GHG emissions.

- Increase security and quality of energy supply.

- Realizing RE targets.

Although the initial idea for the project may focus on a few of these advantages (the industrial enterprise will no doubt focus on cheaper energy; the local enthusiast may focus on environmentally friendly solutions) it is important to realize that this in no way detracts from other advantages of the project. This becomes essential when communicating the idea to other stakeholders.

Communication with other stakeholders is very important, as it will take the combined efforts of a larger group of stakeholders to bring the idea to fruition in the form of a successfully operating project.

\subsection{Pre-feasibility study}

The pre-feasibility study is the initial assessment of the potential project. It is a basic review of the main aspects of the project. The purpose is to decide if it is worth taking the project forward and invest further money and time.

It is at this stage that the Excel screening tool we describe in section 5 becomes useful. The Excel tool will allow you to fairly quickly set up comparisons between as many as three variations on your basic idea, and also give you the ability to compare these to the current situation (reference scenario). As your project develops and the need for precise estimates increases, you have the option of supplying the tool with local data on climate, prices and energy consumption. This will allow you to also use the Excel tool for the more detailed analysis in the feasibility study which we describe below. 


\subsection{Feasibility study}

The feasibility study consists of a detailed assessment of all aspects of the project. The purpose of the feasibility study is to explore the project in enough detail for the interested stakeholders to make a commitment to proceed with its development.

A feasibility study goes into details with technical design as well as financial, social and environmental impacts. Investment costs (CAPEX), operating costs (OPEX) and environmental impacts are estimated based on a detailed technical description and draft design. The case study we present in chapter 6 is a good example of a technical feasibility study including an economic and financial analysis.

\subsection{Contracts and financing}

The contracts and financing stage takes the project from the feasibility study to Final Investment Decision (FID) by the project owner. The main focus at this stage is securing financing and procurement.

Contractors are typically selected based on bids from several potential contractors. This selection process may vary greatly depending on local procurement rules and legislation. We recommend you consult with a local procurement specialist to ensure that you comply with local rules and regulations.

The outcome of this stage is typically an EPC (Engineering, Procurement and Construction) contract ready for signature which allows the project owner to prepare a fairly accurate investment budget. 


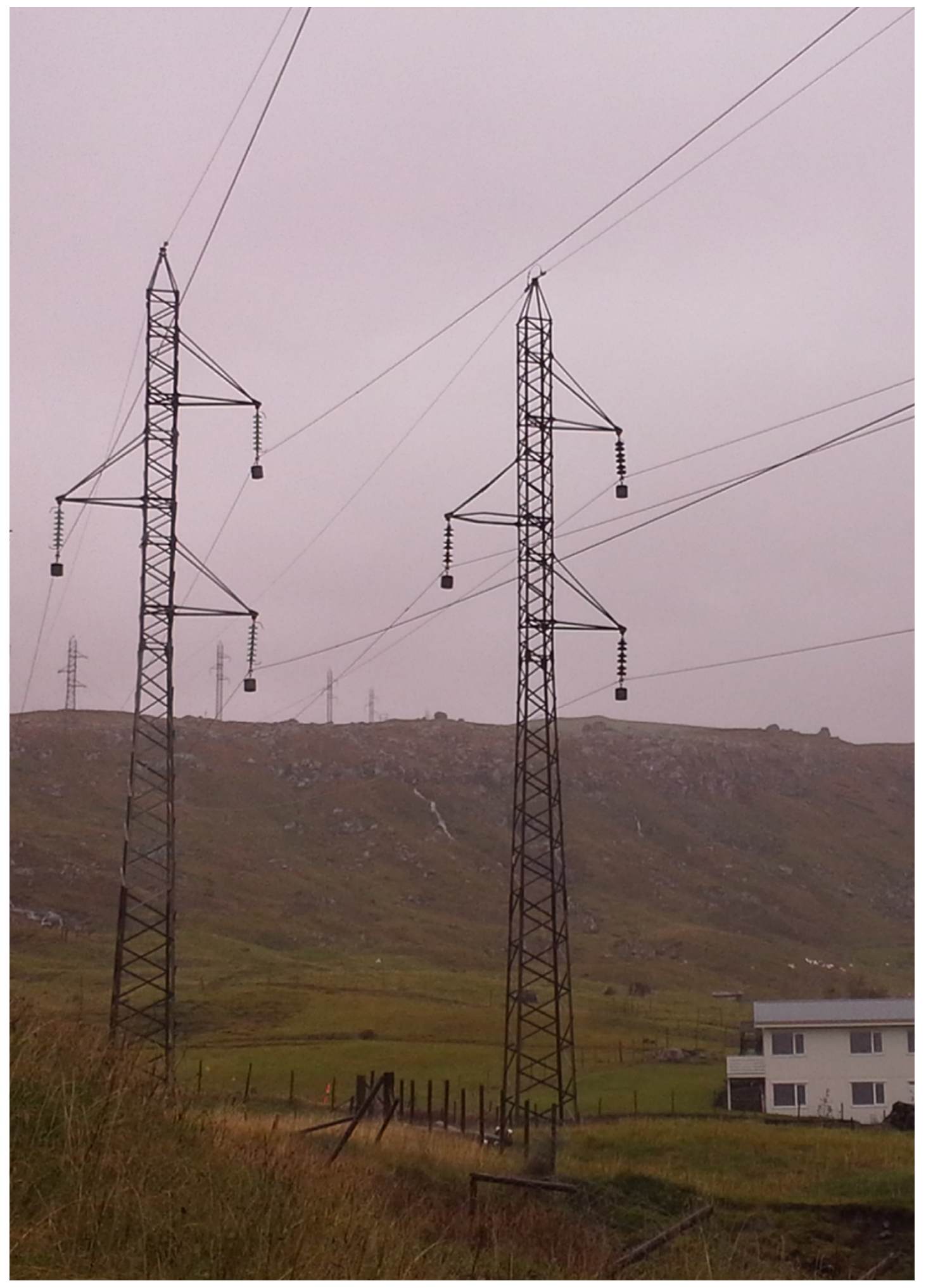




\section{Technology}

In this section, we briefly describe the main technologies that we employ in this guide. The main theme of the guide is how electrification can support a transition towards renewable energy in heating as well as power generation. As a result, most of the technologies we present use electricity as an energy source or produce electricity. For a more in depth look at the technologies please refer to the Catalogue of technologies (Guide Report no. 2).

The technologies we describe are split into three main categories. First we present technologies for heating. Second we present technologies for producing electricity. Last we present technologies for storing heat and electricity.

\subsection{Heating}

Electrification of heating is all about creating synergies with the electricity generation by providing flexible demand and opportunities for storage. In Table 1 we list the main advantages and disadvantages of the technologies that we describe.

Table 1: Pros and cons of heating technologies

\begin{tabular}{lll} 
Technology & Pros & Cons \\
Heat pump & High efficiency & High cost \\
Electric boiler & Low cost & Low efficiency \\
Biomass boiler & Local RES fuel & No synergy with electricity generation \\
\hline
\end{tabular}

\subsubsection{Heat pumps}

Heat pumps use electricity to extract heat from the surrounding environment. Since a large proportion of the heat generated comes from the surrounding environment and not the electricity, the efficiency in terms of energy produced per energy used is very high. The COP (Coefficient Of Performance) varies in the range of $300 \%$ to $400 \%$ of the electricity used depending on the quality and size of the heat pump and the local climate. 
Heat pumps are a very efficient way of converting electricity into heat. However, heat pumps are also quite expensive. The economic viability of heat pumps depends on operating them at close to maximum capacity as often as possible.

\subsubsection{Electric boilers}

Electric boilers are the simplest way of converting electricity to heat. Their efficiency is usually close to $100 \%$, which is still very low compared to a heat pump. On the plus side is the very low cost of electric boilers.

Electric boilers are ideal as a supplement to heat pumps for boosting max capacity in peak load hours.

\subsubsection{Biomass boilers}

Biomass boilers are included in the guide as an alternative to electrification. In some cases electrification may not be an option, or biomass is readily available at low or no cost. Biomass boilers are typically cheaper than heat pumps.

Using biomass as a heat source instead of electrification may make it more difficult to balance the electricity production from intermittent sources like solar power and wind. On the other hand, the availability of biomass may also lead to a consideration of biomass for electricity production.

\subsection{Electricity}

In this guide, we have omitted most technologies based on biomass, as we foresee possible issues with procurement and documenting the $\mathrm{CO}_{2}$ neutrality of biomass. Whether biomass is $\mathrm{CO}_{2}$ neutral or not is still the subject of heated debate - a debate that we will not go into in this guide.

Table 2: Pros and cons of power generation technology

\begin{tabular}{|c|c|c|}
\hline Technology & Pros & Cons \\
\hline Wind turbines & Fuel is free & No control of when the wind blows \\
\hline Photovoltaics & Fuel is free & No control of when the sun shines \\
\hline Hydro power & Flexible production & Requires differences in altitude \\
\hline Bio diesel generator & Flexible production & $\mathrm{CO}_{2}$ emissions are debatable Expensive fuel \\
\hline
\end{tabular}




\subsubsection{Wind turbines}

Wind turbines come in a wide range of designs related to either the amount of electricity they can produce and the wind speeds they can produce at. Wind turbines are typically designed for a specific range of wind speeds at which they produce at their optimum output. The less extreme wind conditions are, the easier it will be to find a suitable wind turbine.

The electricity produced from a wind turbine will be very volatile and will typically need to be balanced by production units or storage facilities under the control of the balancing responsible.

\subsubsection{Solar power (photovoltaics)}

Much like wind, the electricity produced from solar panels is very volatile. In order to deliver a stable and secure supply of electricity, solar power must be balanced by other sources.

Solar power will often be less than ideal in combination with electrification of heat, as the temperature is correlated with sunlight. At higher temperatures, the demand for electricity from heating will be lower, hence when solar panels are producing at their maximum capacity, demand for electricity will be at its lowest.

\subsubsection{Hydro power}

Unlike wind and solar power, hydro power is a flexible renewable energy source. Hydro power can be based on the steady flow of water in a stream or river, or it can be combined with a reservoir to further increase the control of the production of power. Reservoirs can also be used for pumped storage, which will be covered in section 3.3.3.

Hydro power requires the availability of two main components: altitude differentials and large quantities of water. In addition, use of water from the reservoir may come at an opportunity cost, as the same water cannot be used later.

\subsubsection{Bio diesel generator}

Using bio diesel in an existing diesel generator is a short cut to flexible electricity production on a renewable energy source. The bio diesel generator can fill the same role as hydropower by matching the balancing needs of the intermittent production from wind and solar power.

Biodiesel is a direct replacement for fossil diesel and emits the same amount of $\mathrm{CO}_{2}$ when combusted. However, burning biofuels is technically considered $\mathrm{CO}_{2}$ neutral, as the source of the $\mathrm{CO}_{2}$ is expected to regenerate (and bind the $\mathrm{CO}_{2}$ again) with- 
in a short (1-20 years) timespan. It is important to recognise that the status of bio fuels as a renewable and "clean" energy source is debatable and may change. In the short run it is certainly a quick fix to the balancing needs of wind and solar power.

\subsection{Storage}

The ability to store heat and electricity is vital to small-scale systems. Storage provides the means to temporally separate consumption and production. This essentially means that energy can be produced whenever the conditions are beneficial and it can be consumed whenever the need arises. Without storage, energy would have to be produced when and only when it is needed.

Storage of heat serves two main purposes:

- To save up heat for periods when the maximum load is higher than the capacity of the heat sources.

- To produce heat when the price of electricity is low and save it for periods with high prices.

Storage of electricity also serves two main purposes:

- To store excess electricity produced when the sun is shining or the wind is blowing and use it when the sun is not shining or the wind is not blowing.

- To even out spiky production from wind and solar power in the very short run.

Heat and electricity storage are to some degree substitutes when heating is electrified. Excess electricity can be stored as heat as long as the consumption of heat is sufficiently high. Some electric heating components are sufficiently fast reacting to serve as balancing power when electric production from solar and wind power is spiky.

\subsubsection{Hot water tank}

The concept is simple - heat water up and store it in an insulated tank for later use. Designing hot water tanks for minimal heat loss and maximum heat recovery is complicated. Even though the design is complicated, hot water tanks are easily scaled to match the system and are relatively low cost.

Hot water tanks cannot convert heat back into electricity. 


\subsubsection{Batteries}

Batteries store electricity as electricity and can be discharged with a loss of $15 \%-30 \%$. The price of batteries has been steadily dropping for long time, but batteries are still quite expensive. The price of batteries is high enough that long term storage of electricity in batteries is still not realistic.

Batteries may have a role to play as short term balancing for intermittent production. On the Faroe Islands the local energy provider SEV is using batteries to balance a ${ }_{15} \mathrm{MW}$ wind farm in Tórshavn with good results.

\subsubsection{Pumped hydro storage}

Electricity can be stored in water by pumping water up into the reservoir of a hydro power facility. The increasingly efficient pumps available today coupled with basically free excess electricity from wind and solar power is what makes this solution attractive. Several conditions must be met before pumped hydro storage is viable:

- The availability of a reservoir upstream of the hydro power plant.

- Excess capacity in the reservoir - if the reservoir is full or is expected to be filled by precipitation or glacial runoff then filling it with pumped water will only lead to overfilling.

- Excess electricity production from sources like wind and solar power.

- A source of water downstream - if the hydro power plant is not producing then the discharge in the river may be too low.

Pumped hydro storage could also be designed to work without connection to a fresh water source. Instead the facility could pump sea water up into a tank on a hilltop or some other elevated location.

\subsection{Smart energy management}

Smart energy management and smart grid are two sides of one coin. These terms refer to a wide range of technologies aimed at increasing the synergies between energy production and consumption. The common themes are communication, coordination and control. In the following we present three of the most common components to a smart grid and smart energy management. In chapter 3 we go into more detail with 
the system benefits that can be achieved using these technologies in combination with electrification of heating and $100 \%$ renewable electricity production.

\subsubsection{Data hub}

The ability to communicate and coordinate production and consumption relies heavily on a constant two-way flow of information. Real time data on consumption patterns flow from consumers to producers, while real time data on energy prices flow from producers to consumers. This is a very large amount of data which may require investments in improved data infrastructure.

\subsubsection{Centralized override}

In some cases the control of heating units and other installation using electricity may be turned over to, for example, the local balancing responsible. In this way, energy demand becomes an asset to the balancing responsible on the same level as backup generation. To make it worthwhile, the consumer is typically compensated for the loss of control. This kind of centralized control takes advantage of the data flow described above.

\subsubsection{Autonomous units}

Another way to improve the flexibility of demand is to install "intelligent" semiautonomous units in the consumers' homes. These units are able to tap into the flow of data between producers and consumers in order to optimize energy consumption.

The most common example of this would be a refrigerator which shuts off for shorter periods of time whenever the frequency of the electricity falls below a certain threshold. Another example could be household battery units which charge when the price of electricity is low and discharge when the price is high. 


\section{Energy systems}

In this section we combine the technologies into systems. In small-scale systems, it is very difficult to achieve the same flexibility as large-scale systems because of a lack of technological diversity. We combine technologies to achieve as much flexibility and as many synergies as possible within the limited frame of small-scale energy systems.

\subsection{System benefits}

In this guide, we use the term "System benefits" to signify the monetary benefit from the synergies generated by electrification of heating and storage of heating. These synergies result in a more stable, predictable and flexible energy consumption pattern which has a direct impact on the price and cost of energy. Producing heat when there is an excess of electricity being produced (e.g. plenty of wind and sun) is privately profitable because the price of electricity will often be lower at these times.

The same privately profitable actions are also a benefit to the power generator and the system responsible for two reasons:

1. The increased demand from heating reduces the need to curtail wind or solar power production units - thus increasing the overall utilization and profitability of these units.

2. The stored heating can potentially be used in periods with very low electricity production (e.g. no wind and no sun) reducing the need to produce electricity on less efficient units - ultimately reducing the need to invest in generation capacity.

These two benefits should over time lead to lower costs of producing and balancing electricity and in turn to lower prices of electricity.

System benefits play different roles in on-grid and off-grid systems. In on-grid systems, any system benefits that electrification of heating can provide may be used as a bargaining chip to negotiate favourable electricity prices for heating. In off-grid systems the joint heating and power generation system should be designed to take advantage of system benefits in order to minimize investments. 


\subsection{Heating (On grid)}

The heating systems described below are all based on heat pumps - either individual heat pumps or large heat pumps providing district heating. All require a water based system of heat dispersion in the homes. In Norway and Sweden, many homes are heated by electric resistance radiators. Converting these homes to water based heat systems is likely not feasible, as it would require a significant investment in retrofitting the house with hot water pipes and radiators.

Even in small communities, it is unlikely that all households' heating installations are the same age. This can be a challenge when it comes to implementing collective solutions like district heating, as these solutions would require a rapid conversion of all household installations in order to be feasible. Households which have recently invested in a new heat installation will have very little incentive to replace their brand new installations.

\subsubsection{Individual heat pumps}

Each home replaces its existing heat source with a heat pump drawing heat from e.g. the ground or the air. The heat pump is backed up by a small electric boiler and a hot water tank.

This is the solution with the highest household investment. On a positive note, this solution does not require any kind of collective decision and it can be implemented whenever the existing heat source reaches the end of its technical life.

\subsubsection{Individual heat pumps with collective heat source}

Each home replaces its existing heat source with a heat pump drawing heat from a collective low temperature water distribution net. The heat pump is backed up by a small electric boiler and a hot water tank.

This solution has lower household investment, but in return requires a collective investment in the cold water distribution system. The individual heat pumps provide some flexibility to the rate of implementation among the households, but the feasibility of the collective distribution system will depend on most households connecting to it.

\subsubsection{Large heat pump district heating}

A large heat pump delivers heat to a district heating system. The heat pump is backed up by a large electric boiler and a large hot water tank. 
This solution has the lowest household investment, but the largest community investment in heat pump and high temperature water distribution net. The collective nature of this system requires a very high rate of connection among the households. It also limits the flexibility in terms of timing of the conversion for the individual household.

\subsection{Electricity and heating (Off grid)}

Off grid communities need to produce their own electricity. Converting such small scale power generation to renewable energy poses some challenges, but it also provides the opportunity to base the generation on $100 \%$ renewable energy, something users connected to a large scale power grid do not have much influence over.

Unless the community is situated close to an unused source of hydro power, wind turbines and solar power will play a vital role in reaching the goal of $100 \%$ renewable energy. The volatile nature of wind power and solar power poses a big challenge as they need to be balanced by other more flexible sources or by storage.

Below we present three different scenarios for providing electricity in sparsely populated areas.

\subsubsection{Wind/solar with balancing power}

The simplest possible $100 \%$ renewable energy setup that includes intermittent production would be to replace fossil diesel with bio diesel. The diesel generator will provide balancing against the volatile electricity from wind and sun.

This setup has the benefit of having a high margin for error and it will allow the community to reuse any existing diesel generators. The downside is that bio diesel is expensive and the climate impact is debatable, especially when taking into account energy used for producing it and transporting it.

\subsubsection{Wind/solar with short term storage and backup}

Combining electrification of heating with intermittent power production provides some interesting system benefits. A heating system with an electric boiler as a backup and hot water storage tank can provide a significant amount of power and storage balancing. It might even be feasible to use the electric boiler even when the heat is not needed simply as an alternative to balancing with a battery or a flexible generation unit.

The system will still depend on a backup bio diesel generator or a small hydro power unit for those cloudy days with no wind. 


\subsubsection{Long term storage}

Pumped hydro storage is an option that could solve a lot of the challenges posed by intermittent power production. Pumped hydro storage does not need to be connected to a river, stream or lake. It could be based on pumping sea water instead.

Combining pumped hydro storage and electrification and storage of heat provides a very flexible system. No single component of the combined heat and power system needs to be designed to take the full load. Heat pump and electric boiler backup, combined with a heat storage tank, will be able to deliver plenty of heat. Intermittent power production combined with balancing from the electric boiler, hydro power, storage of heat, and pumped hydro power, can shift large quantities of electricity when it is nesessary.

Unfortunately pumped hydro storage also has limitations. First, pumped hydro storage has some of the same geographical challenges as regular hydro power - you need elevation. Second it can be quite expensive to install.

\subsection{Next steps}

In the previous two chapters we have provided an overview of a selection of renewable energy technologies and energy technologies and insight on how to combine them in systems that rely on $100 \%$ renewable energy sources. In Guide Report no. 2 we have provided data on all the technologies described here. This data is the backbone of the Excel screening tool, which is also a part of this guide and which we present below.

In the next chapters we first present an Excel tool that we have developed to assist you in determining the feasibility of implementing a 100\% renewable energy system in your community. Next we present a case from Leirvík on the Faroe Islands, where we assessed three alternative heating solutions based on heat pumps.

In Guide Report no. 4 we describe the process of developing a renewable energy project from initial idea to feasibility study and financing. 


\section{Excel screening tool}

As part of this guide, we have made an Excel tool to help local planners and decision makers take the first steps in screening potential solutions for their community. The tool combines local data provided by the user with the data provided in the technology data sheets to calculate simple key indicators for three separate design scenarios compared to the current situation.

The tool will provide a rough estimate of the feasibility of different designs of the future energy system. Each alternative system design is called a scenario.

\section{$5.1 \quad$ Outputs}

We start with the outputs of the tool to give you an understanding of what information this tool can provide.

Figure 1: Output module of the Excel decision tool
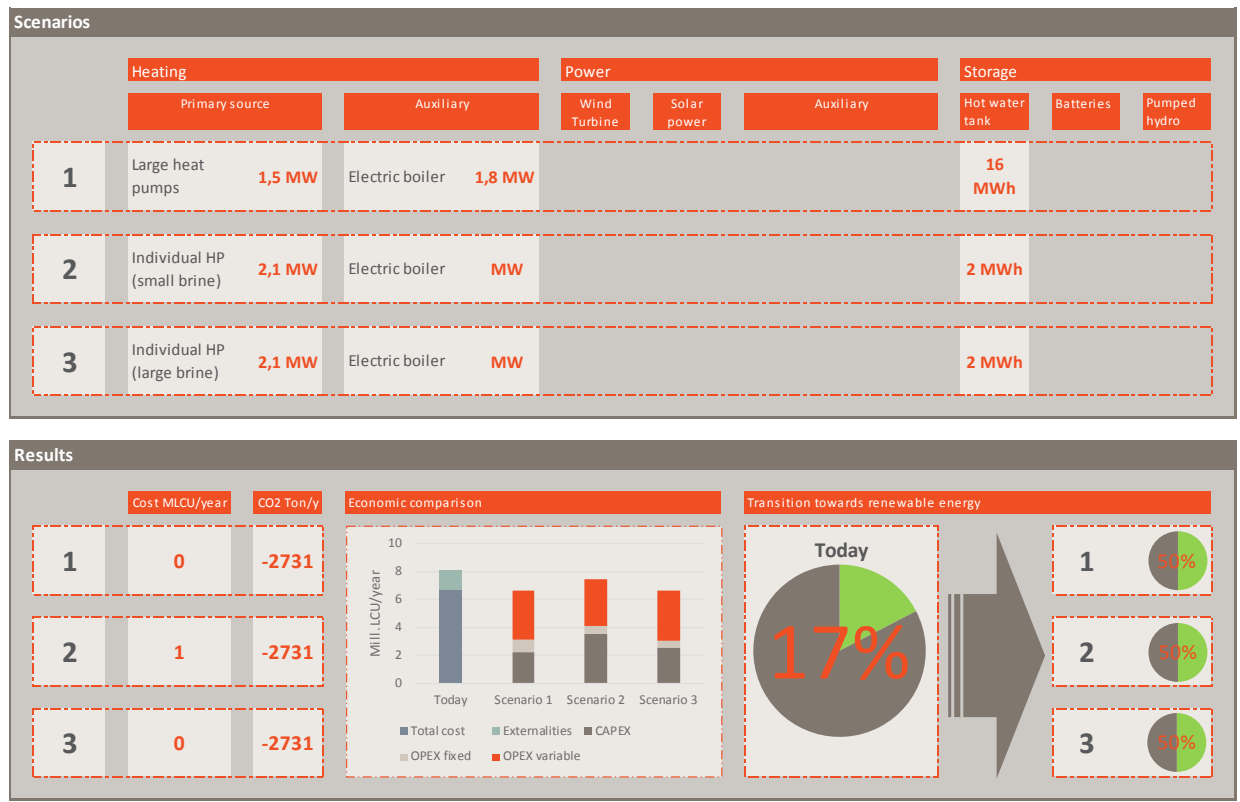


\subsection{1 $\mathrm{CO}_{2}$ savings and RES share}

$\mathrm{CO}_{2}$ savings and renewable energy as a share of total energy produced (RES share) is the motivation for the entire project. Otherwise, it is safer and easier to simply reinvest in a new diesel generator or oil heater.

For on-grid solutions, the tool takes into account the RES share and $\mathrm{CO}_{2}$ emissions from the electricity provided by the grid. This is based on inputs by the user as we do not have knowledge of local conditions. It also means that the RES share will likely never be $100 \%$ unless the grid provides electricity from $100 \%$ renewable sources.

For off grid solutions we only provide options for designing systems with $100 \%$ renewable energy.

\subsubsection{Total annual cost}

The main indicator of an economically feasible project is the total annual cost. This cost includes financing of the investment and operation and maintenance. The design scenarios will always include at least two separate technologies with separate technical life spans. In order to compare investments with differing durations, we convert all investments to annuities.

In Guide Report no. 3 we go into detail with the methodology behind economic and financial analyses.

\subsubsection{Externalities}

We valuate emissions to air according to the damage they do. We have valuated $\mathrm{CO}_{2}$, $\mathrm{CH}_{4}, \mathrm{~N}_{2} \mathrm{O}, \mathrm{SO}_{x}, \mathrm{NO}_{x}$ and particles according to Danish guidelines. It is possible to change these values if your local valuation is very different from the one we have used.

\subsection{Data}

The tool uses a wide range of data. All of the data can be changed to reflect local conditions. For basic data and scenario definition we have made user-friendly interfaces, while for the more advanced data like hourly climate data and consumption patterns we expect the user to have a good understanding of Excel. 


\subsubsection{Basic data}

Basic data is data about the community: Size, population, number of buildings, heat demand, electricity demand etc. We also ask for data on the current production of heat and electricity.

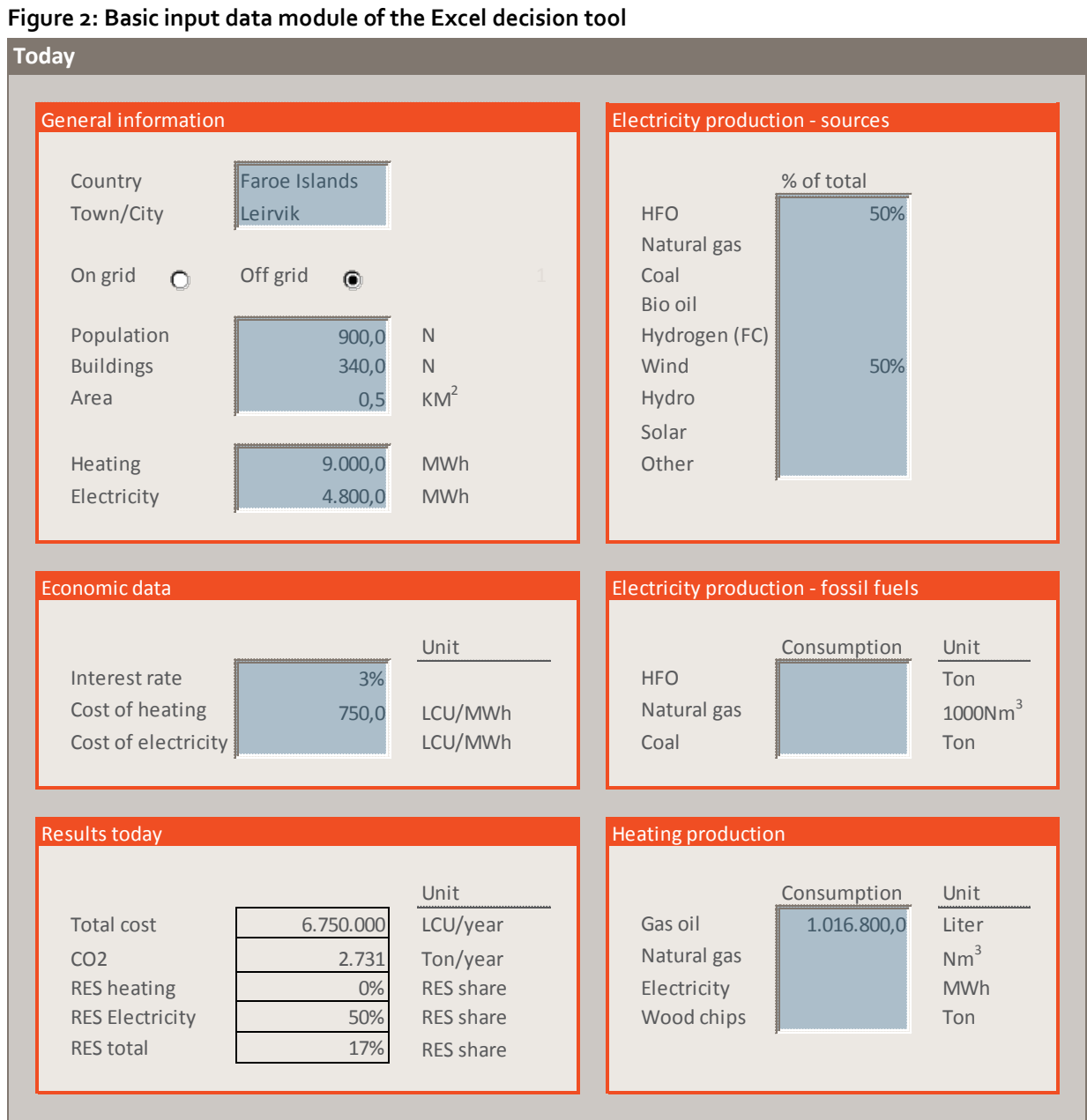

\subsubsection{Scenario definition}

In scenario definition we ask the user to define three scenarios for supplying the community with heat and electricity (only off grid). To assist the user we have provided several key figures such as maximum heat load, needed storage capacity given the 
current design capacity and needed backup capacity. As you plot in you system design these figures will change to let you know if you are on track.

Figure 3: Scenario definition module of the Excel decision tool

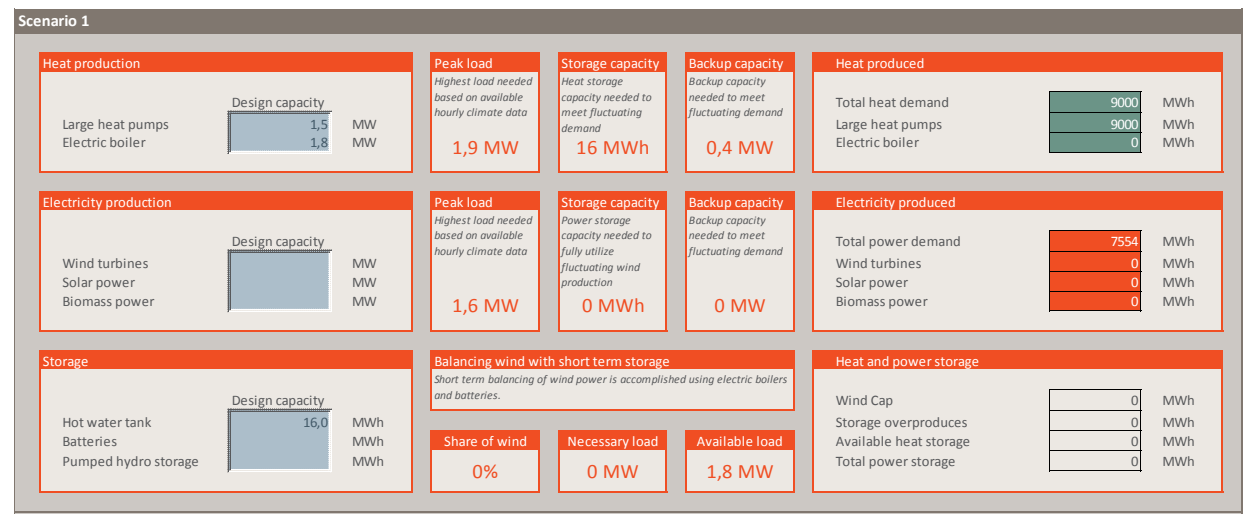

\subsubsection{Hourly data}

We have provided data on temperature for every hour of a year on the Faroe Islands as well as production data ( $\mathrm{MWh}$ ) from $1 \mathrm{MW}$ wind turbine and $1 \mathrm{MW}$ photovoltaic panels. Lastly, we have also provided electric consumption data (excluding heating).

Data on temperature and production from wind turbines and photovoltaic panels will vary greatly with local conditions and can have a large impact on the results. $R e-$ placing these data with local data should be your top priority.

\subsubsection{Technology datasheets}

The technology datasheets are presented in Guide Report no 2, and they are an important part of the screening tool. This data will be outdated very fast, so we have made sure that it is fairly easy to update them with new data on prices and efficiency. 


\section{Case: Leirvík}

A part of the project for Nordic Energy Research has been a case study of the heating supply to the community of Leirvík in the Faroe Islands. The case study is based on the principles laid out in this guide and has also provided valuable feedback to the formulation of the guide.

This section demonstrates how to put together a heat supply system based on renewable energy for a small community exemplified by Leirvík on the Faroe Islands. Leirvik is an on-grid community where electricity is supplied by the national grid on the Faroe Islands, which means that the renewable energy share in electricity is outside the control of Leirvík.

The case study went through the following steps:

- Consultations with local and governmental stakeholders.

- Selection of technical solutions for further study.

- Detailed design of technical solutions.

- Cost estimates.

- Economic and financial analysis.

- Presentation of results to the local community.

The process we went through in the case is a very close match to the one described in Guide Report no. 4- except for the initial and final stages of the process described in the guide. In Leirvík the project idea was already well rooted in the local community and the basic concept of using heat pumps had been developed. Building upon the feasibility study developed in the case study (in 2016), Leirvík will proceed into the final stages of project development by seeking financing and governmental support (in 2017).

In the following, we present a brief overview of the most important facts and results from the case study. The detailed report on the case study is available in Guide Report no. 1. 


\subsection{Leirvík today}

Leirvík is a small city of approximately 800 inhabitants and 340 buildings. The geographical conditions are very common for the Faroese cities. It is near the sea with steep cliffs at its back. All buildings in Leirvík are supplied with electricity from the central electricity grid on the Faroe Islands. On average, the electricity in the central grid is based on $66 \%$ renewable energy ( $20 \%$ wind and $46 \%$ hydro power).

Heating is based on individual oil boilers. The oil consumption for heating in Leirvík is approximately 1.1 million litres of oil pr. year. Based on a heat efficiency assumed to be $85 \%$ for the oil boilers the oil consumption converts to an annual heat demand of approximately 9,000 MWh.

In the following the situation of Leirvik today will be referred to as the reference scenario.

\subsection{Scenarios}

The case study examined three alternative scenarios for electrification of heating. These are:

- Scenario 1: Individual heat pumps, individual brine.

- Scenario 2: Individual heat pumps, shared brine.

- Scenario 3: Seawater heat pump, district heating.

The alternative scenarios were defined in collaboration with the local and governmental stakeholders.

In this case study, the three project scenarios have much higher investment costs compared with the reference scenario. However, the energy cost is much higher in the reference scenario.

\subsection{Results}

The annual project cost of the four scenarios is shown in Figure 4 . 
Figure 4: Annual project costs in the four scenarios. Electricity prices are different during day and night but the same for small and large consumers

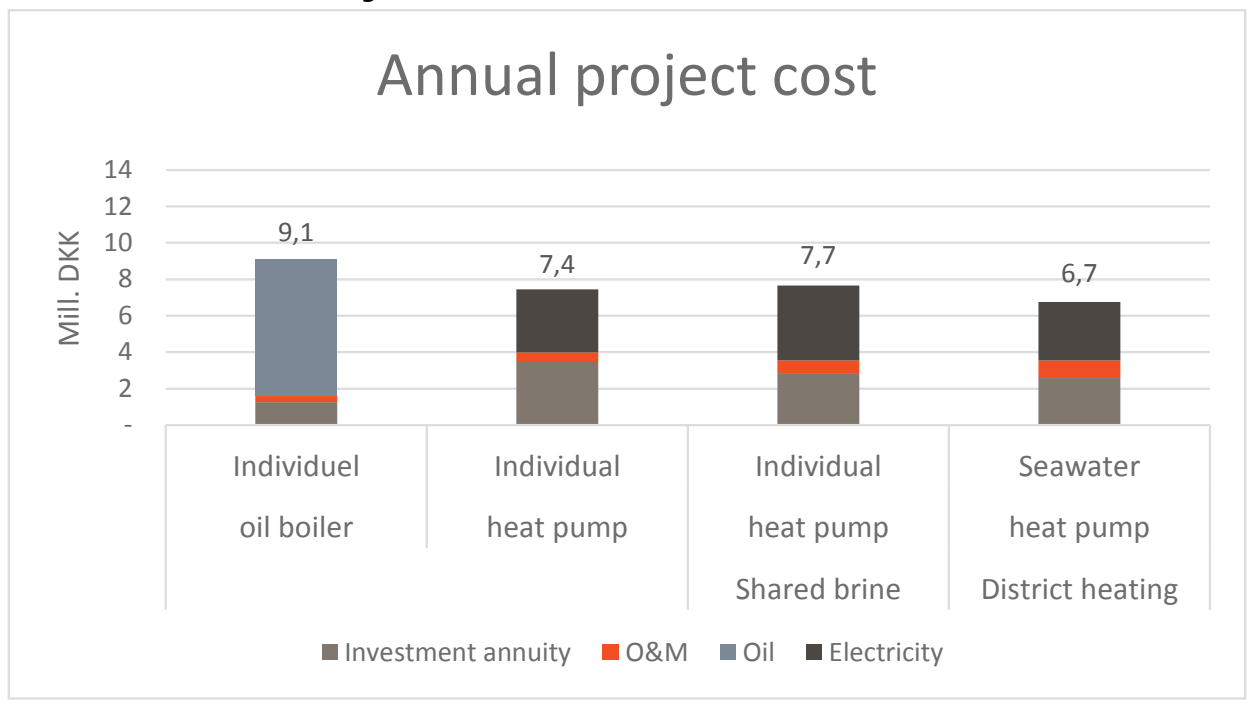

Note: O\&M refers to Operations and Maintenance.

The reference scenario has the highest annual costs and the district heating scenario has the lowest annual costs. The two other scenarios are almost equal in the annual costs.

The results are based on an assumption that electricity prices are the same for small and large consumers. Sensitivity analysis has shown that differentiating prices for small and large consumers will not alter the relative ranking of the alternatives, although district heating will benefit the most.

\subsection{Comparing alternatives}

In this case study, the main conclusion is that the conversion from fossil fuels to renewable heat production in sparsely populated areas is not just possible but also feasible. In this project, three alternative solutions for supplying heat to Leirvik were analysed. All three scenarios are feasible compared with the current heating system based on oil boilers.

The two scenarios with individual heat pumps (small and large brine) are almost equal with regard to the annual costs. The individual heat pump scenario where each building has its own brine pipe system is easy to implement when each building is independent of other buildings. For shared systems (such as the shared brine scenario) most buildings should be connected to the system relatively fast for it to remain feasible. 
The district heating scenario is the most feasible of the scenarios. This is due to the high efficiency of the heat production units and the possibility of using electricity at periods with lower electricity production price.

The advantage of the district heating system is also the flexibility with regard to the heat production units. If at some point some new production possibility occurs (e.g. a more efficient heat pump) it is possible to add this to the district heating network. In the scenarios with individual heat pumps it will be a much more comprehensive and prolonged process to change more than 300 units.

One of the central assumptions in this case study is the use of heat pumps to implement wind power in the electricity system. Here district heating has the advantage of having only a few units (heat storage tank, heat pump, electric boiler) in the same location, which need to be controlled. In the individual heat pump scenarios (small and large brine) there will be a need for controlling more than 300 units in just as many locations. This will not only be more difficult to manage but it can also cause further investments in the electricity system in the buildings. In addition to this the total storage capacity is much higher in the district heating scenario compared with the other scenarios. 


\section{Sammenfatning}

Nordic Energy Research bad i 2016 COWI om at løse en todelt analyse af mulighederne for at øge anvendelsen af vedvarende energi i spredt bebyggede egne i Norden. De to dele af analysen var:

- En generel guide, der kan hjælpe lokale planlæggere og politikere i gang med planlægningen af vedvarende energiprojekter i spredt bebyggede områder

- Et case studie af mulighederne for at anvende vedvarende energi i varmeforsyningen til Leirvík på Færøerne

Spredt bebyggede områder og samfund er ikke en entydigt defineret enhed. I forbindelse med energiforsyning er det primære formål med anvendelsen af udtrykket "spredt bebyggede områder og samfund", at give udtryk for at der er tale om små samfund, der i vid udstrækning selv er ansvarlige for deres energiforsyning. I forbindelse med denne analyse har vi yderligere opdelt disse samfund i to grupper:

- On grid: Samfund der er forbundet til et større nationalt eller regionalt elforsyningsnetværk.

- Off grid: Samfund der ikke er forbundet til et større nationalt eller regionalt elforsyningsnetværk.

Denne opdeling har været nødvendig, fordi det har stor betydning for muligheden for at basere energiforsyningen på vedvarende energi. On grid samfund har meget begrænset indflydelse på anvendelsen af vedvarende energi i el-produktionen, da denne er styret af nationale og regionale målsætninger. Hvis et On grid samfund opstiller en vindmølle, vil det kun bidrage marginalt til den samlede andel af vedvarende energi i elproduktionen.

Analysens fokus på spredt bebyggede områder bunder i en erkendelse af, at disse områder har både nogle særlige udfordringer og muligheder i forbindelse med anvendelsen af vedvarende energi. På den ene side er de afhængige af nogle få produktionsenheder, der står for hele energiforsyningen. Det stiller høje krav til driftssikkerhe- 
den. På den anden side giver uafhængigheden i energiforsyningen mulighed for i højere grad selv at styre udviklingen mod $100 \%$ vedvarende energi.

\section{Guide}

Guiden henvender sig til lokale planlæggere og politikere, der ønsker mere viden om mulighederne for at konvertere energiforsyningen i lokalsamfundet til vedvarende energi. Guiden er bygget op af en række delrapporter og et Excel værktøj. Dokumentationen til casestudiet fra Leirvík indgår også som en del af guiden.

Guiden består af følgende dokumenter:

- Guide: Hoveddokument, der fungerer som vejviser til de andre documenter.

Dokumentet er et udvidet executive summary, der giver en første indføring i de vigtigste elementer: Proces, teknologier, systemer og smart grid, Excel værktøj og casestudie.

- Guide Report 1: Rapport om casestudiet fra Leirvík på Færøerne.

- Guide Report 2: Teknologikatalog, der præsenterer fakta om de enkelte teknologier og hvordan de passer sammen i energisystemer.

- Guide report 3: Bilag om samfundsøkonomisk og financiel analyse

- Guide report 4: Bilag om styring af projekter inden for vedvarende energi

- Excel Decision Tool: Excel baseret værktøj til samfundsøkonomisk og finansiel screening af alternative løsninger i energiforsyningen

Et centralt punkt i guiden er, at vi anbefaler at varmeforsyningen elektrificeres. Elektrificering giver mulighed for at udnytte de meget høje virkningsgrader i varmepumper og at lagre overskydende elproduktion som varme for derved at skabe synergier mellem el- og varmeforsyningen. Disse synergier er bl.a. med til at muliggøre integrationen af mere vind- og solenergi i elsystemet.

\section{Casestudie}

Leirvík på Færøerne er en bygd med ca. 850 indbyggere og ca. 340 bygninger, der alle, med få undtagelser, opvarmes med oliefyr. Det giver anledning til et samlet forbrug af fyringsolie i Leirvík på ca. 1,1 million liter om året. Leirvík er forsynet med el fra det nationale el-net på Færøerne, hvilket betyder at Leirvík er det vi har defineret som On 
grid. Leirvik har meget begrænsede muligheder for direkte at påvirke indholdet af vedvarende energi i el-produktionen.

Casestudiet undersøger tre forskellige alternative scenarier for opvarmning af bygdens bygninger:

1. Individuelle varmepumper baseret på jordvarme.

2. Individuelle varmepumper baseret på en kollektiv varmekilde i form af en væske der har samme temperatur som havvandet og som pumpes rundt til bygningerne i nedgravede rør.

3. Fjernvarme baseret på en stor varmepumpe der trækker varme direkte ud af havvandet.

I casestudiet finder vi frem til at for Leirvíks vedkommende ser fjernvarmeløsningen ud til at være den økonomisk og teknisk mest fordelagtige løsning. Med forbehold for usikkerheder i omkostningsoverslagene på investeringer og drift og vedligehold er alle tre alternative løsninger billigere end en videreførelse af den eksisterende oliebaserede opvarmning. 
Nordic Council of Ministers

Ved Stranden 18

DK-1061 Copenhagen K

www.norden.org

\section{Renewable energy supply and storage}

How to shift to renewable energy systems in sparsely populated areas? This guide provides tools for initiative takers and planners, to explore the potential in local resources and provide sustainable electricity and heating for thecommunity. The guide includes a step-by-step guide through the project development process and presents advantages and challenges of optional technologies and energy systems, including heating and electricity from wind, sun, sea and fresh water, biomass and the ground.

The focus of this guide is on implementation of renewable energy solutions in sparsely populated areas, based upon proven technologies that are available in the market, and to design reliable and affordable energy systems. Energy storage and smart energy management get special attention. Facts and numbers from a pilot project in Leirvik at the Faroe Islands illustrates how to use this guide.

Supplementary:

- an Excel based screening tool: Include data for your own local community and analyse the feasibility of optional solutions for renewable energy systems.

- Guide Report no. 1: Case report from Leirvík in the Faeroe Islands including technical appendices to document the design of three case scenarios

- Guide Report no. 2: Catalogue of technologies and renewable energy systems which presents hard facts about each technology and how the technologies fit together

- Guide Report no. 3: Further information on financial and cost benefit analysis

- Guide Report no. 4: Further information on organisational, social and regulatory considerations

Available for download at http://www.nordicenergy.org/publications/

Other relevant reports from Nordic Energy Research:

- Nordic Energy Technology Perspectives 2016 (published 2016)

- Wind power based pumped storage, Faroe Islands (published 2013)

- $\quad$ Fælles nordisk studie om pumped storage (published 2012)

- $\quad$ Energisystem i glesbygd (published 2011)

Available for download at http://www.nordicenergy.org/publications/

TemaNord 2016:563

ISBN 978-92-893-4805-8 (PRINT)

ISBN 978-92-893-4806-5 (PDF)

ISBN 978-92-893-4807-2 (EPUB)

ISSN 0908-6692

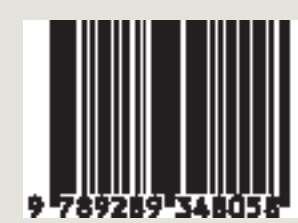

